\title{
Differences in vitamin D status and calcium metabolism in Saudi Arabian boys and girls aged 6 to 18 years: effects of age, gender, extent of veiling and physical activity with concomitant implications for bone health
}

\author{
Maryam A Al-Ghamdi ${ }^{1,2, *}$, Susan A Lanham-New ${ }^{1}$ and Jalal A Kahn ${ }^{2}$ \\ ${ }^{1}$ Nutrition and Metabolism Department, Faculty of Health and Medical Sciences, University of Surrey, Guildford \\ GU2 7XH, UK: ${ }^{2}$ Biochemistry Department, King Abdulaziz University, Jeddah, Kingdom of Saudi Arabia
}

Submitted 6 October 2010: Accepted 12 December 2011: First published online 21 February 2012

\begin{abstract}
Objective: Few data exist looking at vitamin D status and bone health in schoolaged boys and girls from Saudi Arabia. The present study aimed to determine the extent of poor vitamin D status in school boys and girls aged 6-18 years and to examine if there was any difference in status with age, physical activity and veiling and concomitant effects on bone.

Design: Cross-sectional study.

Setting: Jeddah, Kingdom of Saudi Arabia.

Subjects: A total of 150 boys (7-16 years) and 150 girls (6-18 years) from local schools were divided into age categories: 6-9 years (elementary school); 10-12 years (secondary school); 13-14 years (middle years); 15-18 years (high school). Results: Vitamin D status was significantly lower in girls than boys in all age groups $(P<0 \cdot 01)$, with the 15-18-year-old girls having the lowest level $(22 \cdot 0$ (SD $9 \cdot 4) \mathrm{nmol} / \mathrm{l})$ in comparison to the $15-18$-year-old boys $(39 \cdot 3(\mathrm{sD} 14 \cdot 0) \mathrm{nmol} / \mathrm{l})$ and the 6-9-year-old girls $(41 \cdot 2(\mathrm{SD} 9 \cdot 3) \mathrm{nmol} / \mathrm{l})$. Parathyroid hormone status was highest in the 15-18-year-old girls in comparison to boys of the same age. A total of $64 \%$ of 15-18-year-old girls had 25-hydroxyvitamin D (25OHD) status $<25 \mathrm{nmol} / \mathrm{l}$ in comparison to $31 \%$ in the $13-14$ years age category, $26 \%$ in the $10-12$ years category and $2.5 \%$ in the $6-9$ years category. No boys had $25 \mathrm{OHD}$ status $<25 \mathrm{nmol} / \mathrm{l}$. Fully veiled girls had lower $25 \mathrm{OHD}$ status than partly veiled or unveiled girls $(P<0 \cdot 05)$. Low $25 \mathrm{OHD}$ and high parathyroid hormone was associated with lower bone mass in the 6-9 years and 13-14 years age groups $(P<0 \cdot 05)$.

Conclusions: These data suggest significant hypovitaminosis D in older adolescent females, which is a cause for concern given that there is currently no public health policy for vitamin D in the Kingdom of Saudi Arabia.
\end{abstract}

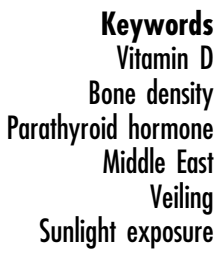

The Middle East registers the highest rates of low vitamin D status worldwide ${ }^{(1)}$, despite its abundant sunshine and geographical location, which spans latitudes from $12^{\circ} \mathrm{N}$ to $42^{\circ} \mathrm{N}$, allowing vitamin $\mathrm{D}$ synthesis year $\operatorname{round}^{(1-4)}$. However, few data are available comparing vitamin D status and bone health in school-aged boys and girls within the same study design in the Middle East region generally and in the Kingdom of Saudi Arabia (KSA) specifically $^{(4,5)}$.

The Arabian Gulf countries, namely KSA, Kuwait, Oman, Qatar, Bahrain and the United Arab Emirates, have similar demographic, social, cultural and environmental characteristics. These countries have experienced rapid economic and social changes during the past two decades, resulting in a marked improvement in lifestyle and health status $^{(6-11)}$. However, these rapid changes have led to the development of a paradoxical situation regarding nutrition, in that both a lack of and an excess of nutrition coexist. Undernutrition has manifested as growth retardation/bone deformity among pre-school children and Fe-deficiency anaemia, while overnutrition has manifested as obesity, dental caries and non-communicable disease ${ }^{(5,7-11)}$.

A number of studies suggest that rickets is more common in Arab countries than is reported in Western countries. Furthermore, the prevalence of vitamin D deficiency is significantly higher in Arab women and children than in the white population ${ }^{(12-15)}$. Sedrani et al. reported that severe hypovitaminosis D (25-hydroxyvitamin D (25OHD) level $\leq 20 \mathrm{nmol} / \mathrm{l}$ ) was present in $52 \%$ of Saudi females aged $35 \cdot 4$ (SD 11.3) years ${ }^{(16)}$, but few data exist 
comparing age-matched boys and girls in Saudi Arabia within the same study design ${ }^{(17)}$. There is a lack of data directly comparing younger and older school-aged Saudi boys with younger and older girls and also few studies examining whether vitamin $\mathrm{D}$ is lower in veiled girls compared with the unveiled population. This is particularly important given the high percentage of females in KSA who are veiled from puberty.

The principal aim of the present study therefore was to determine the extent of vitamin D 'deficiency/insufficiency' in Saudi Arabian young males and females aged 6-18 years and subsequently to investigate the impact of low vitamin D status and poor lifestyle habits (particularly physical activity levels and exposure to sun) on markers of bone health in this age group. The specific objectives were to determine: (i) the percentage of the population with $25 \mathrm{OHD}$ level below $25 \mathrm{nmol} / 1, \quad 40 \mathrm{nmol} / 1, \quad 50 \mathrm{nmol} / 1$ and $75 \mathrm{nmol} / 1$; (ii) whether $25 \mathrm{OHD}$ levels differ in boys $v$. girls and in older $v$. younger age groups; (iii) the impact of puberty, physical activity and veiling on $25 \mathrm{OHD}$ levels in girls; (iv) the association between $25 \mathrm{OHD}$ and parathyroid hormone (PTH) levels; and (v) the association between 25OHD, PTH and markers of bone health as assessed by lumbar-spine and whole-body bone mineral content/density, broadband ultrasound attenuation and markers of bone resorption. Our a priori hypotheses were that there would be a difference in 25OHD status between the older boys and girls but not the youngest boys and girls and that veiling would not have a significant impact on $25 \mathrm{OHD}$ given the age of the girls. We also predicted that low $25 \mathrm{OHD}$ status would be associated with poor bone health in the different age groups.

\section{Materials and methods}

\section{Study design and participants}

An observational, cross-sectional study was conducted on school-aged males and females. A total of 300 schoolchildren aged 6-18 years were included in the study (150 boys and 150 girls). All samples were collected during the month of May, following permission from the Ministry of Education. Schools were selected to allow a range of socio-economic status groups to be included in the study. Ethical approval was given by the Ministry of Education and King Abdulaziz University Hospital Ethics Committee. The study conformed to the guidelines of the Declaration of Helsinki (1964). All volunteers were given a detailed oral presentation about the study at their school. Study information was sent to all children and their parents, and a signed a consent form was received from both the child and his/her parent/legal guardian prior to participation in the trial. No children suffered from any condition or were taking any medicine likely to affect their bone metabolism.

The questionnaires included questions about health and socio-economic status, mode and onset of veiling, sequence of the child in the family, level of parental education, consanguinity between the parents and the duration of daily sun exposure. Within the questionnaire we also asked specific questions on the extent of physical activity levels (in number of hours per week) for the following activities: walking, swimming, cycling, aerobics and running. The children completed the questionnaires at home with their parents; those who were interested in participating in the study returned the questionnaires back to school with their parents' signature and telephone numbers included. Fifty per cent of the children completed the questionnaire at school with the parents' consent. The other $50 \%$ completed the questionnaire with their parents by telephone. Finally all of the questionnaires were then collected by the researcher.

A total of 150 boys (prepubertal: $n$ 118, 78.7\%; postpubertal: $n$ 32, 21.3\%) and 150 girls (prepubertal: $n$ 51, $34 \cdot 0 \%$; postpubertal: $n$ 99, 66.0\%) were studied. Pubertal status was determined using an interview-based series of discrete questions rather than the formal use of Tanner staging, which culturally would have been unacceptable in this population group - both in terms of parents and the school authorities specifically. For the analysis, we grouped the children according to the different school age groupings in KSA: 6-9 years (elementary school); 10-12 years (secondary school); 13-14 years (middle years); and 15-18 years (high school). We thought this a sensible approach in the absence of being able to verify pubertal status biochemically or by use of Tanner staging for the reasons given above. This provided a tight focus in looking at both age and gender differences and the groups were well matched in terms of the number of children in each of the different categories. In the questionnaire that we used to assess the start of menarche among the girls, no female had started her periods before age 10 years and so we are confident that the 6-9 years age group is prepubertal; moreover, we estimate it is very likely that the 10-12 years group is peripubertal and the 13-14 years and 15-18 years groups are postpubertal.

\section{Exclusion criteria}

The exclusion criteria for the study were as follows: (i) children younger than 6 years and older than 18 years; (ii) children who suffered from any disease that might interfere with vitamin D synthesis including skin, liver, kidney and gastrointestinal diseases, or any disease that might affect bone status such as diabetes, asthma, heart disease, rheumatoid arthritis, hyperthyroidism and thalessaemia (these diseases imply the intake of certain medications such as cortisone and insulin that have been shown to negatively affect bone mineral density, this information was obtained via a questionnaire); and (iii) children currently taking vitamin supplements or who had taken them within the last 3 months prior to the examination.

\section{Blood collection and assays}

A total of $10 \mathrm{ml}$ fasting blood was extracted from the children by a nurse into a non-heparinized Vacutainer 
tube. The blood samples were allowed to clot for $15-30 \mathrm{~min}$ and then separated in a cold centrifuge $\left(4^{\circ} \mathrm{C}\right)$ at $3500 \mathrm{rpm}$ for $10 \mathrm{~min}$. Serum was aliquoted into labelled $0.5 \mathrm{ml}$ Eppendorf tubes and promptly frozen at $-80^{\circ} \mathrm{C}$ until used for analysis. Vitamin D was measured using the Elecsys 25OHD assay (Roche Diagnostics GmbH, Mannheim, Germany). The assay is a direct electrochemiluminescence immunoassay for human serum or plasma; it is a competitive assay in which the binding protein of vitamin $\mathrm{D}$ is inactivated during incubation and a polyclonal antibody directed against 25OHD is employed. We compared the 25OHD assay with assays performed by RIA. Our laboratory range for $25 \mathrm{OHD}$ was $50-80 \mathrm{nmol} / 1$ and the $\mathrm{CV}$ was $4.5 \%$. Serum PTH was measured using a Roche Diagnostics direct electrochemiluminescence immunoassay; our laboratory range for PTH was 1.6-6.9 pmol/1 and the $\mathrm{CV}$ was $6 \cdot 2 \%$. Serum levels of $\mathrm{Ca}, \mathrm{P}$ and alkaline phosphatase were measured by the Dimension Clinical Chemistry System (Dade Behring Inc., Newark, DE, USA). The system is an integrated chemistry system that provides maximum productivity with the capacity to grow through automation connectivity. The $\mathrm{CV}$ for $\mathrm{Ca}, \mathrm{P}$ and alkaline phosphatase were $5 \cdot 6 \%, 7 \cdot 2 \%$ and $9 \cdot 4 \%$, respectively. The bone formation marker osteocalcin was measured by an antibody-based ELISA kit (DRG Instruments GmbH, Marburg, Germany). The bone resorption marker C-terminal telopeptide of type 1 collagen (CTx) was measured with two monoclonal antibodies against human c-peptide using an Elecsys kit (Roche Diagnostics $\mathrm{GmbH})$. The $\mathrm{CV}$ for osteocalcin and CTx were $7 \cdot 8 \%$ and $9 \cdot 2 \%$, respectively.

\section{Antbropometric measures and bone mineral content}

The weight (in kilograms) and height (in centimetres) of all children were measured using a DETECTO scale (http://www.detectoscale.com) to the nearest $0 \cdot 1 \mathrm{~kg}$ and $0.1 \mathrm{~cm}$; both weight and height were recorded without shoes. BMI was calculated using the standard equation: $\mathrm{BMI}=$ weight $/$ height $^{2}$. Bone mineral content measurements were determined for all children at the lumbar spine (L2-L4) and whole body sites using dual-energy X-ray absorptiometry (QDR4500 instrument; Hologic Inc., Bedford, MA, USA) with its Pediatric software version 11.40.004 (http://www.gehealthcare.com). All measurements were performed at the Centre of Excellence for Osteoporosis Research within the King Fahed Medical Research Centre, Jeddah. The calibration of the absorptiometer was checked daily. Scan area $\left(\mathrm{cm}^{2}\right)$, bone mineral content $(\mathrm{g})$, bone mineral density $\left(\mathrm{g} / \mathrm{cm}^{2}\right)$ and $Z$-score for the lumbar spine and whole body were measured. The CV of this technique was $<0 \cdot 1 \%$. Bone mass was also measured using the broadband ultrasound attenuation technique (Cuba Clinical instrument; McCue Corporation Inc., Warwick, RI, USA) at the calcaneal on the left foot. The CV of this technique was $2 \cdot 2 \%$.

\section{Statistical analysis}

The data were analysed using the SPSS statistical software package version 15 (SPSS Inc., Chicago, IL, USA). Data were checked for normality using the KolmogorovSmirnov test; for those variables found not to be normally distributed, non-parametric analysis was applied. Differences between the groups were analysed using one-way ANOVA with Scheffé post hoc analysis (normally distributed data) or Kruskal-Wallis testing (non-parametric data). Correlations were determined using Pearson (normally distributed data) or Spearman rank (non-parametric data) correlation coefficients depending on the normality of the data. Stepwise multiple regression analysis was used to determine the key factors which explain the variation in $250 H D$ status in boys and girls separately. Using the rule of six participants for each variable entered into the equation, we were able to explore the influence of wide variety of factors on vitamin D status including body size and lifestyle factors. The significance value was set at $P<0.05$ with the full range of $P<0.01$ to $P<0.001$ being applied.

\section{Results}

As shown in Table 1, we grouped the data according to the different school age groupings in KSA: 6-9 years (elementary school); 10-12 years (secondary school); 13-14 years (middle years); and 15-18 years (high school). In the analysis, we have been careful to discuss the findings in relation to the school age groupings rather than our 'estimated' pubertal development. The mean age in the four school age groupings was 8 years, 11 years, 13 years and 15 years, respectively, for both boys and girls. The girls were lighter and shorter in each of the different age groups compared with their male counterparts, undertook less physical activity and had less sun exposure $(P<0 \cdot 05)$. BMI was the same between boys and girls in each age category. In terms of socio-economic status, $51 \cdot 3 \%$ of the population was from non-affluent areas and $48.7 \%$ from affluent areas. There was a difference in the percentage of veiling with all girls in the high school group (15-18 years) being fully veiled, while in the middle years group (13-14 years) $73 \cdot 8 \%$ were fully veiled and $26 \cdot 2 \%$ were partly veiled. In the secondary school group (10-12 years) virtually all girls were partly veiled $(96.5 \%)$, whereas in the elementary school group (6-9 years) $97 \cdot 4 \%$ of the girls were not veiled.

As shown in Table 2, 25OHD status was significantly lower in girls than boys in all four school age groups $(P<0 \cdot 01)$. There was a difference in 250 HD status among girls between the elementary school group (mean age $8.0(\mathrm{sD} 0.9)$ years) and the secondary (mean age 11.3 $(\mathrm{sD} 0 \cdot 8)$ years), middle years (mean age $13 \cdot 2(\mathrm{SD} 0 \cdot 4)$ years) and high school (mean age $15 \cdot 4$ (sD 0.9) years) groups. There was also a difference in 25OHD status 
Table 1 Anthropometric and lifestyle factors in school-aged Saudi Arabian boys and girls $(n 300)$

\begin{tabular}{|c|c|c|c|c|c|c|c|c|c|c|c|c|c|c|c|c|}
\hline & \multicolumn{8}{|c|}{ Boys } & \multicolumn{8}{|c|}{ Girls } \\
\hline & \multicolumn{8}{|c|}{ School age groups } & \multicolumn{8}{|c|}{ School age groups } \\
\hline & \multicolumn{2}{|c|}{$\begin{array}{c}\text { 7-9 years } \\
(n \text { 42) }\end{array}$} & \multicolumn{2}{|c|}{$\begin{array}{c}10-12 \text { years } \\
(n 59)\end{array}$} & \multicolumn{2}{|c|}{$\begin{array}{c}\text { 13-14 years } \\
(n 30)\end{array}$} & \multicolumn{2}{|c|}{$\begin{array}{c}15-18 \text { years } \\
(n 19)\end{array}$} & \multicolumn{2}{|c|}{$\begin{array}{c}\text { 6-9 years } \\
(n \text { 40) }\end{array}$} & \multicolumn{2}{|c|}{$\begin{array}{c}10-12 \text { years } \\
(n 57)\end{array}$} & \multicolumn{2}{|c|}{$\begin{array}{c}\text { 13-14 years } \\
(n \text { 42) }\end{array}$} & \multicolumn{2}{|c|}{$\begin{array}{c}15-18 \text { years } \\
(n 11)\end{array}$} \\
\hline & Mean or $\%$ & SD or $n$ & Mean or $\%$ & SD or $n$ & Mean or $\%$ & SD or $n$ & Mean or $\%$ & SD or $n$ & Mean or \% & $\%$ SD or $n$ & Mean or $\%$ & o SD or $n$ & Mean or \% & SD or $n$ & Mean or $\%$ & SD or $n$ \\
\hline Age (years) & $8 \cdot 2^{a}$ & $0 \cdot 7$ & $11 \cdot 0^{\mathrm{b}}$ & 0.9 & $13 \cdot 4^{\mathrm{C}}$ & 0.5 & $15 \cdot 1^{d}$ & 0.3 & $8 \cdot 0^{a}$ & 0.9 & $11 \cdot 3^{b}$ & $0 \cdot 8$ & $13 \cdot 2^{\mathrm{C}}$ & 0.4 & $15 \cdot 4^{d}$ & 0.9 \\
\hline Weight $(\mathrm{kg})$ & $39 \cdot 9^{a}$ & $22 \cdot 2$ & $47 \cdot 6^{\mathrm{b}}$ & $17 \cdot 5$ & $55 \cdot 2^{\mathrm{b}}$ & $15 \cdot 3$ & $58 \cdot 0^{\mathrm{C}}$ & $14 \cdot 7$ & $28 \cdot 9^{d}$ & $9 \cdot 9$ & $45 \cdot 6^{b}$ & $14 \cdot 3$ & $47 \cdot 5^{b}$ & $8 \cdot 2$ & $46 \cdot 0^{\mathrm{b}}$ & $14 \cdot 1$ \\
\hline Height $(m)$ & $1 \cdot 37^{\mathrm{a}}$ & 0.12 & $1 \cdot 50^{\mathrm{b}}$ & 0.07 & $1 \cdot 60^{c}$ & 0.09 & $1 \cdot 65^{d}$ & 0.08 & $1 \cdot 28^{\mathrm{e}}$ & $0 \cdot 12$ & $1 \cdot 47^{b}$ & 0.08 & $1.55^{\mathrm{e}}$ & 0.08 & $1 \cdot 51^{f}$ & 0.08 \\
\hline $\mathrm{BMI}\left(\mathrm{kg} / \mathrm{m}^{2}\right)$ & $20 \cdot 2$ & $6 \cdot 6$ & $20 \cdot 9$ & $6 \cdot 2$ & $21 \cdot 4$ & $4 \cdot 3$ & $21 \cdot 1$ & $4 \cdot 1$ & $17 \cdot 2$ & $4 \cdot 0$ & $20 \cdot 7$ & $5 \cdot 1$ & $19 \cdot 6$ & $2 \cdot 9$ & $19 \cdot 9$ & $4 \cdot 1$ \\
\hline Physical activity (h/week) & $2 \cdot 9^{a}$ & $2 \cdot 2$ & $5 \cdot 2^{\mathrm{b}}$ & $2 \cdot \overline{4}$ & $5 \cdot 0^{\mathrm{b}}$ & $2 \cdot 5$ & $4 \cdot 5^{\mathrm{b}}$ & 1.5 & $2 \cdot 1^{\mathrm{a}}$ & $1 \cdot 3$ & $2 \cdot 0^{\mathrm{a}}$ & $2 \cdot 3$ & $2 \cdot 5^{\mathrm{a}}$ & $2 \cdot 5$ & $2 \cdot 3^{\mathrm{a}}$ & 1.5 \\
\hline Sun exposure (min/week) & $33 \cdot 6^{a}$ & $29 \cdot 2$ & $42 \cdot 5^{b}$ & $32 \cdot 0$ & $45 \cdot 0^{\mathrm{b}}$ & $32 \cdot 0$ & $58 \cdot 4^{\mathrm{C}}$ & $32 \cdot 0$ & $22 \cdot 0^{d}$ & $14 \cdot 7$ & $19 \cdot 8^{d}$ & $15 \cdot 5$ & $29 \cdot 0^{\mathrm{e}}$ & $29 \cdot 8$ & $44 \cdot 5^{\mathrm{b}}$ & $31 \cdot 6$ \\
\hline Unveiledt & - & & - & & - & & - & & $97 \cdot 4$ & 39 & 3.5 & 2 & - & & - & \\
\hline Partly veiledt & - & & - & & - & & - & & $2 \cdot 6$ & 1 & $96 \cdot 5$ & 55 & $73 \cdot 8$ & 31 & - & \\
\hline Fully veiledt & - & & - & & - & & - & & - & & - & & $26 \cdot 2$ & 11 & 100 & 11 \\
\hline
\end{tabular}

${ }^{\text {a-f }}$ Mean values within a row with unlike superscript letters were significantly different within the different age or gender categories (ANOVA/Kruskal-Wallis test; $P<0.05, P<0.01$ ).

tValues are presented as $\%$ and $n$.

Table 2 Vitamin D status, markers of calcium metabolism and indices of bone health in school-aged Saudi Arabian boys and girls $(n 300)$

\begin{tabular}{|c|c|c|c|c|c|c|c|c|c|c|c|c|c|c|c|c|}
\hline & \multicolumn{8}{|c|}{ Boys } & \multicolumn{8}{|c|}{ Girls } \\
\hline & \multicolumn{8}{|c|}{ School age groups } & \multicolumn{8}{|c|}{ School age groups } \\
\hline & \multicolumn{2}{|c|}{$\begin{array}{l}\text { 7-9 years } \\
(n \text { 42) }\end{array}$} & \multicolumn{2}{|c|}{$\begin{array}{c}10-12 \text { years } \\
(n 59)\end{array}$} & \multicolumn{2}{|c|}{$\begin{array}{c}\text { 13-14 years } \\
(n 30)\end{array}$} & \multicolumn{2}{|c|}{$\begin{array}{c}15-18 \text { years } \\
(n 19)\end{array}$} & \multicolumn{2}{|c|}{$\begin{array}{c}\text { 6-9 years } \\
(n \text { 40) }\end{array}$} & \multicolumn{2}{|c|}{$\begin{array}{c}10-12 \text { years } \\
(n 57)\end{array}$} & \multicolumn{2}{|c|}{$\begin{array}{c}\text { 13-14 years } \\
(n 42)\end{array}$} & \multicolumn{2}{|c|}{$\begin{array}{c}15-18 \text { years } \\
(n 11)\end{array}$} \\
\hline & Mean & SD & Mean & SD & Mean & SD & Mean & SD & Mean & SD & Mean & SD & Mean & SD & Mean & SD \\
\hline $250 \mathrm{OHD}(\mathrm{nmol} / \mathrm{l})$ & $61 \cdot 2^{\mathrm{a}}$ & $14 \cdot 8$ & $55 \cdot 2^{b}$ & $11 \cdot 3$ & $49 \cdot 0^{\mathrm{b}}$ & $12 \cdot 9$ & $39 \cdot 3^{c}$ & $14 \cdot 0$ & $41 \cdot 2^{c}$ & $9 \cdot 3$ & $31 \cdot 6^{d}$ & $9 \cdot 2$ & $29 \cdot 0^{d}$ & $9 \cdot 1$ & $22 \cdot 0^{\mathrm{e}}$ & $9 \cdot 4$ \\
\hline PTH (pmol/l) & $4 \cdot 5^{\mathrm{a}}$ & $2 \cdot 0$ & $6 \cdot 1^{\mathrm{b}}$ & $4 \cdot 4$ & $5 \cdot 7^{\mathrm{b}}$ & $2 \cdot 2$ & $5 \cdot 2^{b}$ & $2 \cdot 0$ & $4 \cdot 9^{a}$ & $2 \cdot 1$ & $9 \cdot 1^{\mathrm{C}}$ & $5 \cdot 5$ & $7 \cdot 2^{C}$ & $4 \cdot 3$ & $13 \cdot 1^{d}$ & 11 \\
\hline $\operatorname{ALP}(\mathrm{U} / \mathrm{I})$ & $241 \cdot 7^{\mathrm{a}}$ & $64 \cdot 3$ & $272 \cdot 3^{a}$ & $75 \cdot 4$ & $300 \cdot 5^{a}$ & $98 \cdot 2$ & $242 \cdot 0^{a}$ & $63 \cdot 6$ & $243 \cdot 5^{a}$ & $60 \cdot 9$ & $260 \cdot 3^{a}$ & $86 \cdot 0$ & $189 \cdot 9^{\mathrm{b}}$ & $97 \cdot 4$ & $134 \cdot 8^{\mathrm{c}}$ & $69 \cdot 3$ \\
\hline CTx $(\mathrm{nmol} / \mathrm{l})$ & 0.80 & 0.37 & 0.98 & 0.45 & $1 \cdot 29$ & 0.47 & $1 \cdot 23$ & 0.54 & 0.87 & 0.39 & 1.08 & $0 \cdot 43$ & 0.93 & 0.37 & $0 \cdot 76$ & 0.21 \\
\hline $\mathrm{OC}(\mathrm{ng} / \mathrm{ml})$ & $36 \cdot 6^{\mathrm{a}}$ & $10 \cdot 8$ & $34 \cdot 5^{\mathrm{a}}$ & $6 \cdot 6$ & $30 \cdot 8^{\mathrm{b}}$ & $8 \cdot 0$ & $33 \cdot 6^{\mathrm{a}}$ & $8 \cdot 0$ & $31 \cdot 8$ & $6 \cdot 1$ & $31 \cdot 1$ & $6 \cdot 8$ & $29 \cdot 5$ & $7 \cdot 5$ & $30 \cdot 2$ & 5.9 \\
\hline LS-BMC (g) & $19 \cdot 3^{a}$ & $6 \cdot 4$ & $25 \cdot 5^{\mathrm{a}}$ & $6 \cdot 8$ & $28 \cdot 0^{\mathrm{a}}$ & $8 \cdot 2$ & $37 \cdot 7^{\mathrm{b}}$ & $6 \cdot 4$ & $16 \cdot 8^{c}$ & $5 \cdot 2$ & $29 \cdot 3^{d}$ & $9 \cdot 8$ & $30 \cdot 4^{d}$ & $8 \cdot 8$ & $35 \cdot 4^{d}$ & $12 \cdot 9$ \\
\hline LS-BMD $\left(\mathrm{g} / \mathrm{cm}^{2}\right)$ & 0.74 & $0 \cdot 12$ & 0.82 & $0 \cdot 10$ & 0.84 & $0 \cdot 14$ & 0.95 & 0.06 & $0.73^{\mathrm{a}}$ & 0.09 & $0.92^{\mathrm{b}}$ & $0 \cdot 19$ & $0.94^{b}$ & $0 \cdot 17$ & $1 \cdot 04^{\mathrm{b}}$ & 0.19 \\
\hline LS Z-score & -0.51 & 0.85 & $-0 \cdot 24$ & 0.95 & $-1 \cdot 33$ & 1.03 & $-1 \cdot 17$ & $0 \cdot 11$ & -0.35 & $0 \cdot 72$ & -0.33 & $1 \cdot 28$ & $-1 \cdot 04$ & $1 \cdot 32$ & $-1 \cdot 25$ & $1 \cdot 48$ \\
\hline WB-BMC (g) & 1305 & 573 & 1673 & 459 & 1914 & 473 & 2169 & 391 & $955^{\mathrm{a}}$ & 314 & $1588^{\mathrm{b}}$ & 502 & $1724^{\mathrm{b}}$ & 403 & $1646^{\mathrm{b}}$ & 585 \\
\hline WB-BMD $\left(\mathrm{g} / \mathrm{cm}^{2}\right)$ & 0.91 & 0.09 & 0.96 & 0.08 & 0.98 & 0.07 & 1.03 & 0.06 & $0.82^{\mathrm{a}}$ & 0.06 & $0.93^{\mathrm{b}}$ & $0 \cdot 10$ & $0.97^{\mathrm{b}}$ & 0.1 & $0.98^{\mathrm{b}}$ & 0.17 \\
\hline WB $Z$-score & $0 \cdot 21$ & $0 \cdot 83$ & $0 \cdot 24$ & $1 \cdot 15$ & -0.67 & $0 \cdot 85$ & -0.73 & 0.25 & -0.68 & 0.43 & -0.65 & 0.93 & -0.94 & 1.04 & -1.95 & $2 \cdot 19$ \\
\hline $\mathrm{BUA}(\mathrm{MHz})$ & $48 \cdot 9$ & $16 \cdot 0$ & $57 \cdot 1$ & $10 \cdot 0$ & 62.9 & $26 \cdot 2$ & $53 \cdot 0$ & $9 \cdot 6$ & $33 \cdot 3^{a}$ & $12 \cdot 4$ & $54 \cdot 5^{\mathrm{b}}$ & $18 \cdot 8$ & $50 \cdot 9^{\mathrm{b}}$ & $10 \cdot 9$ & $60 \cdot 0^{c}$ & $29 \cdot 7$ \\
\hline
\end{tabular}

25OHD, 25-hdroxyvitamin D; PTH, parathyroid hormone; ALP, alkaline phosphatase; CTx, C-terminal telopeptide of type 1 collagen; OC, osteocalcin; LS, lumbar spine; BMC, bone mineral content; BMD, bone mineral density; WB, whole body; BUA, broadband ultrasound attenuation.

${ }^{a-e}$ Mean values within a row with unlike superscript letters were significantly different within the different age and gender categories (ANOVA/Kruskal-Wallis test; $P<0.05, P<0.01$ ). 
Table 3 Percentage of school-aged Saudi Arabian boys and girls ( $n 300$ ) with $250 \mathrm{OD}$ status $<25 \mathrm{nmol} / \mathrm{l},<40 \mathrm{nmol} / \mathrm{l},<50 \mathrm{nmol} / \mathrm{l},<75 \mathrm{nmol} / \mathrm{l}$ and $>75 \mathrm{nmol} / \mathrm{I}$

\begin{tabular}{|c|c|c|c|c|c|c|c|c|}
\hline & \multicolumn{4}{|c|}{ Boys } & \multicolumn{4}{|c|}{ Girls } \\
\hline & \multicolumn{4}{|c|}{ School age groups } & \multicolumn{4}{|c|}{ School age groups } \\
\hline & $\begin{array}{l}7-9 \text { years } \\
(\%, n 42)\end{array}$ & $\begin{array}{c}10-12 \text { years } \\
(\%, n 59)\end{array}$ & $\begin{array}{c}13-14 \text { years } \\
(\%, n 30)\end{array}$ & $\begin{array}{c}15-16 \text { years } \\
(\%, n 19)\end{array}$ & $\begin{array}{l}6-9 \text { years } \\
(\%, n 40)\end{array}$ & $\begin{array}{c}10-12 \text { years } \\
(\%, n 57)\end{array}$ & $\begin{array}{c}13-14 \text { years } \\
(\%, n 42)\end{array}$ & $\begin{array}{c}15-18 \text { years } \\
(\%, n 11)\end{array}$ \\
\hline \multicolumn{9}{|l|}{$250 H D$} \\
\hline$<25 \mathrm{nmol} / \mathrm{l}$ & - & - & - & - & $2 \cdot 5$ & $26 \cdot 3$ & $31 \cdot 0$ & $63 \cdot 6$ \\
\hline$<40 \mathrm{nmol} / \mathrm{l}$ & $7 \cdot 1$ & $3 \cdot 4$ & $20 \cdot 0$ & $26 \cdot 3$ & $45 \cdot 0$ & $56 \cdot 2$ & $57 \cdot 1$ & $36 \cdot 4$ \\
\hline$<50 \mathrm{nmol} / \mathrm{l}$ & $21 \cdot 5$ & $37 \cdot 5$ & $40 \cdot 0$ & $26 \cdot 0$ & $32 \cdot 5$ & $15 \cdot 7$ & 9.5 & - \\
\hline$<75 \mathrm{nmol} / \mathrm{l}$ & $61 \cdot 9$ & $50 \cdot 8$ & 33.3 & $47 \cdot 7$ & $20 \cdot 0$ & $1 \cdot 8$ & $2 \cdot 4$ & - \\
\hline$>75 \mathrm{nmol} / \mathrm{l}$ & $9 \cdot 5$ & $8 \cdot 3$ & $6 \cdot 7$ & - & - & - & - & - \\
\hline Total & $100 \cdot 0$ & $100 \cdot 0$ & $100 \cdot 0$ & $100 \cdot 0$ & $100 \cdot 0$ & $100 \cdot 0$ & $100 \cdot 0$ & $100 \cdot 0$ \\
\hline
\end{tabular}

25OHD, 25-hdroxyvitamin D.

among females between the high school group and the secondary school and middle years groups. A similar pattern was evident in the boys across the four age groupings $(P<0 \cdot 05)$. The $15-18$-year-old girls had lower 25OHD status than the boys in the same age category $(P<0 \cdot 05)$. Concomitantly, PTH was significantly higher for females in the 10-12 years and the 15-18 years age groups compared with the youngest group (6-9 years); a similar finding was seen in the youngest group of boys compared with the older age groups. PTH was significantly higher in the older girls than the older boys. There were no differences in serum Ca levels between any of the groups (data not shown). Alkaline phosphatase was significantly different in the 13-14-year-old boys compared with other age groups and significantly different in the 13-14-year-old and 15-18-year-old girls. No differences were found for osteocalcin in any of the age or gender groups.

Table 3 shows the percentage of children below the cut-off points for 25OHD status of $<25 \mathrm{nmol},<40 \mathrm{nmol} / \mathrm{l}$, $<50 \mathrm{nmol} / 1$ and $<75 \mathrm{nmol} / 1$ and $>75 \mathrm{nmol} / 1$. These cutoff points were chosen for their representation of vitamin D 'deficiency', vitamin D 'insufficiency' and vitamin 'suboptimacy', respectively. A total of $63.6 \%$ of the older girls (15-18 years) had vitamin D levels below $25 \mathrm{nmol} / \mathrm{l}$ in comparison to $31.0 \%$ in the 13-14 years category, $26 \cdot 3 \%$ in the $10-12$ years category and $2.5 \%$ in the 6-9 years category. No boys in any of the age groups were below this cut-off point. All of the older girls (15-18 years) were below $40 \mathrm{nmol} / 1$ for $25 \mathrm{OHD}$ status in comparison to $26 \cdot 3 \%$ of the boys of the same age. For the younger (6-9 years) age group, $80 \cdot 0 \%$ of the girls were below $50 \mathrm{nmol} / 1$ in comparison to only $28.6 \%$ in boys of the same age group. Similarly, for the girls in the 10-12 years and the 13-14 years age categories, the percentage below $50 \mathrm{nml} / 1$ was $98 \cdot 2 \%$ and $97 \cdot 6 \%$ respectively in comparison to only $40.9 \%$ and $60.0 \%$ in the boys of the same age groupings.

The levels of 25OHD status with respect to the extent of veiling were examined. In KSA, veiling is mandatory when a female commences puberty but some girls start prior to this, according to the religious beliefs of the family. As shown in Table 4, there was no difference in 25OHD status in the 6-9 years and 10-12 years age categories between the unveiled and partly veiled (showing face and hands) girls, although the numbers in the latter groups were very low ( $n 1$ and $n 2$, respectively). There were no females in the young age category who were fully veiled. However, in the 13-14 years age group, there was a statistically non-significant trend for the fully veiled girls to have lower 25OHD than the partly veiled girls $(27 \cdot 4(\mathrm{sD} 7 \cdot 5) \mathrm{nmol} / \mathrm{l}$ v. $29 \cdot 6$ (SD 9.6) $\mathrm{nmol} / \mathrm{l})$. All of the girls in the oldest age group (15-18 years) were fully veiled and had significantly lower 25OHD status in comparison to the fully veiled and partly girls in the 13-14 years age category. When the females were categorized into prepubertal and peri/postpubertal groupings (also shown in Table 4) according to menstrual status, in the latter group 25OHD status was significantly lower in the fully veiled females $(24 \cdot 7$ (sD $8 \cdot 7) \mathrm{nmol} / \mathrm{l})$ compared with the partly veiled females (30.8 (sD 9.4) nmol/l) and similarly the partly veiled females had lower 25OHD status than the unveiled females $(35.4$ (SD 6.5) nmol/l; $P<0 \cdot 01$ ).

We undertook correlational analysis of cross-sectional data to examine the associations between the markers of vitamin D status and Ca homeostasis (namely PTH) and markers of bone health (namely CTx, alkaline phosphatase and bone mineral content as assessed by dual-energy X-ray absorptiometry and broadband ultrasound attenuation) in the different school age categories for boys and girls, and some results are presented in Table 5. A significant negative correlation was found between 25OHD status and PTH in the 6-9 years and 13-14 years female age groups but not the 15-18 years age group (data not shown; $P<0 \cdot 001$ ), which may possibly be explained by the low number of girls in this older age group. A significant positive correlation was found between 25OHD status and lumbar-spine bone mineral density in the $6-9$ years and $13-14$ years age categories. A significant positive correlation was also found 


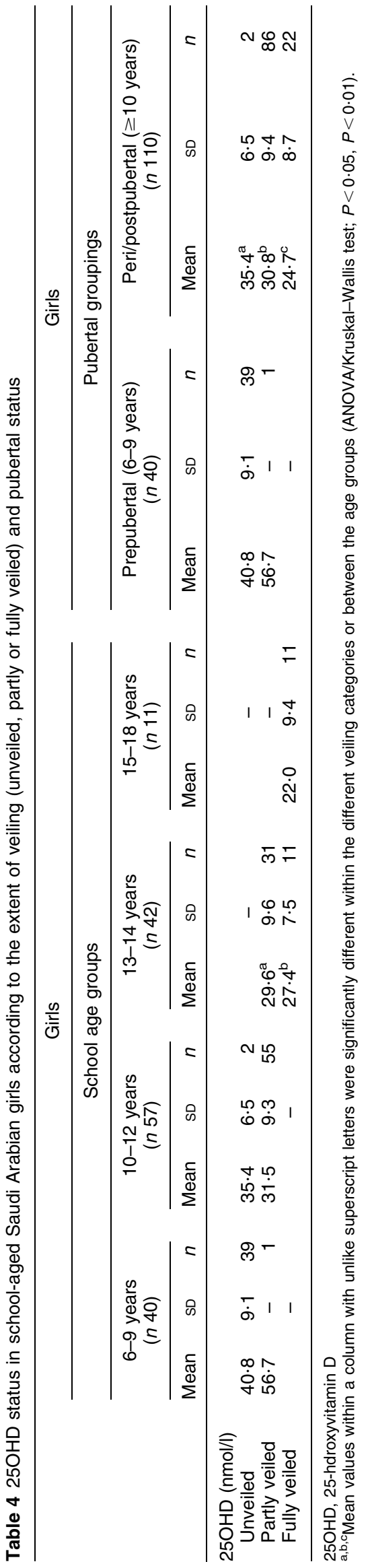

between $25 \mathrm{OHD}$ status, CTx and whole-body bone mineral content in the 13-14 years age category. These remained significant after adjustment for weight and height $(P<0 \cdot 05)$. No correlations were found between $250 \mathrm{HD}$ status and markers of Ca metabolism/bone health in the boys (data not shown) and no correlations were found between 25OHD status and markers of bone health in the older girls (data not shown), which is likely to be due to the low number of participants in this older age group for the females.

We then examined the data further to establish which factors explained the variation in 25OHD status in the school-aged children using stepwise multiple regression analysis, examining the boys and girls separately. Using the rule of no less than six participants per variable entered into the regression model, we used 25OHD as our dependent variable and included age, PTH, alkaline phosphatase, CTx, osteocalcin, extent of veiling (girls only), time spent outside, physical activity, socio-economic status, history of bone fractures, weight, height, bone pain and mother's history of fractures as our independent variables. We included two models for the analysis of females to enable the effect of age and the effect of veiling to be looked at independently. As shown in Table 6, for the boys, only height was a significant predictor of $25 \mathrm{OHD}$ status, explaining $24.9 \%$ of the variation in vitamin D status. For the girls, two models are shown. For model 1, veiling, PTH and osteocalcin were the key predictors explaining $47 \cdot 3 \%$ of the variation in vitamin D status. For model 2, age, PTH and osteocalcin were the key predictors explaining $51.6 \%$ of the variation in vitamin $\mathrm{D}$ status.

We did not find any consistent associations between physical activity levels and vitamin D status in any of the gender/school age groups. However, we did identify differences in 25OHD status in young boys who reported continuous bone pain (59.4 (SD 15.3) nmol/1 v. 51.9 (SD 11.1) nmol/1; $P<0 \cdot 05)$ but no significant findings in the other groups. 25OHD status was also significantly lower in older boys who reported continuous muscle pain $(54 \cdot 2$ (SD $11 \cdot 8) \mathrm{nmol} / 1 v \cdot 47 \cdot 0(\mathrm{sD} 11 \cdot 3) \mathrm{nmol} / \mathrm{l} ; P<0 \cdot 05)$ and a statistically non-significant trend was shown for the older girls $(30 \cdot 3(\mathrm{SD} 10 \cdot 4) \mathrm{nmol} / 1$ v. $27 \cdot 4(\mathrm{sD} 8 \cdot 3) \mathrm{nmol} / \mathrm{l})$.

\section{Discussion}

The main objective of the present study was to determine the extent of poor vitamin D status in school-aged boys and girls, and to examine if there was any difference in vitamin D status with chronological age, physical activity level, extent of veiling and the subsequent effects on bone health indices. We primarily wanted to make comparisons within the same study design, since there is a considerable lack of data directly comparing younger and older Saudi boys with younger and older Saudi girls. Little is also known as to whether vitamin D status is lower in veiled girls compared with the unveiled population. We also wanted to 
Table 5 Correlation coefficients between 25OHD status and markers of calcium metabolism and bone health in school-aged Saudi Arabian girls

\begin{tabular}{|c|c|c|c|c|c|c|c|c|}
\hline & \multicolumn{8}{|c|}{ Girls aged 6-9 years (elementary school) } \\
\hline & PTH & CTx & $\mathrm{OC}$ & LS-BMD & LS-BMC & WB-BMD & WB-BMC & BUA \\
\hline \multirow{4}{*}{$\begin{array}{l}\text { 25OHD (nmol/l) } \\
\text { PTH (pmol/l) }\end{array}$} & $-0 \cdot 41^{\star \star}$ & NS & NS & $0.52^{*}$ & $0 \cdot 46^{\star}$ & $0 \cdot 61^{\star \star \star}$ & $0 \cdot 58^{\star *}$ & NS \\
\hline & - & NS & NS & $-0 \cdot 31$ & $-0 \cdot 66^{\star \star \star}$ & $-0 \cdot 43^{*}$ & $-0 \cdot 61^{\star \star}$ & $-0.56^{\star *}$ \\
\hline & \multicolumn{8}{|c|}{ Girls aged $13-14$ years (middle years) } \\
\hline & PTH & CTx & $\mathrm{OC}$ & LS-BMD & LS-BMC & WB-BMD & WB-BMC & BUA \\
\hline 25OHD (nmol/l) & $-0 \cdot 49^{\star \star \star}$ & $0 \cdot 44^{\star \star \star}$ & NS & $0.55^{\star}$ & $0 \cdot 61^{*}$ & $0 \cdot 64^{*}$ & 0.55 & NS \\
\hline
\end{tabular}

25OHD, 25-hdroxyvitamin D; PTH, parathyroid hormone; CTx, C-terminal telopeptide of type 1 collagen; OC, osteocalcin; LS, lumbar spine; BMD, bone mineral density; BMC, bone mineral content; WB, whole body; BUA, broadband ultrasound attenuation.

Significance of Pearson/Spearman correlation coefficients: ${ }^{\star} P<0 \cdot 1,{ }^{\star \star} P<0 \cdot 05,{ }^{\star \star \star} P<0.01$.

Table 6 Stepwise multiple regression analysis to determine factors which explain the variation in 25OHD status in school-aged Saudi Arabian boys and girls (6-18 years)

\begin{tabular}{|c|c|c|c|c|c|}
\hline & $\begin{array}{l}\text { Boys } \\
(n 150)\end{array}$ & & & $\begin{array}{c}\text { Girls } \\
(n 150)\end{array}$ & \\
\hline $\begin{array}{l}\text { Model 1: } \\
\text { Constant: }\end{array}$ & $\begin{array}{c}R^{2}=24.9 \% \\
128.5 \mathrm{nmol} / \mathrm{l} \\
-0.49 \times \text { height }\end{array}$ & $P<0.01$ & $\begin{array}{l}\text { Model 1: } \\
\text { Constant: } \\
\text { Model 2: } \\
\text { Constant: }\end{array}$ & $\begin{array}{c}R^{2}=47.3 \% \\
31.7 \mathrm{nmol} / \mathrm{I} \\
-6.9 \times \text { veiling } \\
-0.625 \times \mathrm{PTH} \\
+0.542 \times \mathrm{OC} \\
R^{2}=51.6 \% \\
41.7 \mathrm{nmol} / \mathrm{l} \\
-1.9 \times \mathrm{age} \\
-0.603 \times \mathrm{PTH} \\
+0.491 \times \mathrm{OC}\end{array}$ & $\begin{array}{c}P<0.01 \\
P<0.005 \\
P<0.05 \\
P<0.002 \\
P<0.004 \\
P<0.02\end{array}$ \\
\hline
\end{tabular}

Variables entered stepwise into the multiple regression equation: age, parathyroid hormone (PTH), alkaline phosphatase, C-terminal telopeptide of type 1 collagen (CTx), osteocalcin (OC), time spent outside in the sunlight, continuous bone pain, weight, height, socio-economic status, history of fractures, mother's history of fractures, veiling (girls only), $P<0.05$ to $P<0.001$.

explore whether low vitamin D status is associated with lower bone mineral density in this age cohort.

We found extensive hypovitaminosis $\mathrm{D}$ in the older girls (15-18 years), with $64 \%$ being below $25 \mathrm{nmol} / \mathrm{l}$. Boys had consistently higher 25OHD status at each of the different age groups: 6-9 years, 10-12 years, 13-14 years and 15-18 years. Vitamin D status declined with age in both gender groups and there was a consistent $\sim 10-20 \mathrm{nmol} / \mathrm{l}$ difference in $25 \mathrm{OHD}$ between the different age groups in both genders. In the oldest girls, $100 \%$ were below $40 \mathrm{nmol} / 1$ for $25 \mathrm{OHD}$ compared with approximately half of the prepubertal (6-9 years old) girls being below this level and $10-20 \%$ of the boys. These results of low $25 \mathrm{OHD}$ existed with significantly higher PTH values for the older girls. It is important to note that the number of participants in our older age cohort was small.

Vitamin D deficiency has also been observed in Kuwait $^{(7,14,18)}$ and the United Arab Emirates ${ }^{(17)}$. The association of low vitamin D in mothers and their infants has been reported in $\mathrm{KSA}^{(14)}$, Kuwait ${ }^{(19)}$ and the United Arab Emirates ${ }^{(20,21)}$. Vitamin D deficiency represented by low levels of 25OHD has been found to be common among adolescents, as shown by studies in KSA and other Gulf countries. In KSA, $75 \%$ of children with rickets had serum $25 \mathrm{OHD}$ below $20 \mathrm{nmol} / 1$ v. $25 \%$ of controls ${ }^{(4)}$.
A study by Sedrani et al. ${ }^{(16)}$ reported 25OHD levels in university students (twenty-six males and thirty-three females) aged 18 to 26 years and in twenty-four elderly persons. The level of 25OHD was significantly lower in the elderly persons $(P<0 \cdot 001)$ than in young students of both sexes, and was significantly higher in females than in males. Levels below $25 \mathrm{nmol} / \mathrm{l}$ were reported in studies by Siddiqui and Kamfar ${ }^{(22)}$ and Al-Jurayyan et al. ${ }^{(23)}$.

Our study is the first reported in the literature to directly compare boys with girls and the differences in 25OHD status with age in KSA. Many studies conducted in the Middle East have shown that a deficiency in vitamin D is more prevalent in females than males, but few have examined the age range 6-18 years. Vitamin D deficiency was investigated in young children and adolescents in Lebanon $^{(2,17)}$. Low levels of vitamin D have been reported in male and female high-school students ( $n$ 318, 153 boys and 165 girls) aged 14-18 years from Isfahan, Iran. The total percentage with $25 \mathrm{OHD}$ status $<50 \mathrm{~mol} / 1$ was $46 \cdot 2 \%$ $(72 \cdot 1 \%$ in females and $18 \cdot 3 \%$ in males). Vitamin D deficiency has been shown to be common in high-school students and, similarly with our findings, was about four times common in female than males ${ }^{(19)}$. For religious reasons, it is usual for females at puberty to cover most of their body with traditional black veiling, leaving the face 
and hands (which are also sometimes covered). Our data suggest that 25OHD status was lower in fully veiled females but further research is required to identify the factors contributing to this. This is a key finding, since females in the Middle East are deprived of adequate sun exposure necessary for bone health and other health outcomes.

There are few data in KSA showing an association between poor vitamin D status and indices of bone health as we present here. However in a study by El-Desouki et $a l^{(24)}$, bone mineral density in adult Saudi females attending a metabolic bone disease clinic was shown to be markedly affected, which may be due to specific environmental factors $^{(16,24,25)}$. El-Hajj Fuleihan ${ }^{(1)}$ showed that low vitamin D levels may be associated with musculoskeletal health across different age groups and with poor muscle function and increased fall risk and osteoporotic fractures in the Middle East. Females tend to have less sun exposure due to social cultural reasons, lack of awareness of the importance of sun exposure for bone health and for cosmetic reasons.

Furthermore, there are few studies showing a link between 25HOD status and bone/muscle pain as we report here in both boys and girls. This was an interesting finding and certainly warrants further investigation. Vitamin D deficiency has been shown to cause muscle weakness and muscle aches and pains in both children and adults. Glerup et al. reported that $88 \%$ of Danish women of Arab descent who presented with muscle pains and weakness were severely vitamin D-deficient ${ }^{(26,27)}$. Bischoff et al. observed that adults with vitamin D deficiency had muscle weakness and were more likely to fall $^{(28)}$. Few data exist on children/adolescents. The finding in our boys of more muscle pain with higher vitamin D levels is difficult to explain and there are very few data in this age group. Furthermore, it is also difficult to explain why the oldest boys had the highest sunshine exposure (about an hour per week, nearly twice as much as the youngest boys) but their 25OHD status was only half that of the youngest boys. This requires further investigation and the potential mechanisms should be more fully explored.

There are a number of limitations of our study. First is our assessment of pubertal status. Pubertal status was determined using an interview-based series of discrete questions rather than the formal use of Tanner staging, which culturally would have been unacceptable in this population group. Hence, we categorized children into school age groupings to enable age-matched comparisons. It was not possible to take adequate blood samples for biochemical confirmation. Second, our 25OHD measurements were not undertaken as part of any vitamin D external quality assessment scheme (such as DEQAS) as there is no system for DEQAS or other similar body in KSA that was available for us to use or indeed for measurements undertaken on children. However, our Elecsys assays were undertaken with meticulous attention, with biochemistry expert guidance and all samples were undertaken in duplicate. The CV of our technique in our hands was good.

\section{Conclusions}

Vitamin D status was significantly lower in the girls than the boys in all age groups, with the high-school girls (15-18 years) having the lowest level in comparison to the high-school boys and the elementary-school girls (6-9 years). Concomitantly, PTH was highest in the 15-18year-old girls in comparison to boys of the same age. A total of $64 \%$ of $15-18$-year-old girls had $25 \mathrm{OHD}$ status below $25 \mathrm{nmol} / 1$ in comparison to $31 \%$ in the 13-14 years age category, $26 \%$ in the $10-12$ years category and $2.5 \%$ in the $6-9$ years category. No boys had $25 \mathrm{OHD}<25 \mathrm{nmol} / 1$. Fully veiled girls had lower $25 \mathrm{OHD}$ status than partly veiled or unveiled girls. Low 25OHD and high PTH was associated with lower bone mass in the 6-9 years and 13-14 years age groups. These data suggest significant hypovitaminosis D in older adolescent females, which is a cause for concern given that there is currently no public health policy for vitamin D in KSA.

\section{Acknowledgements}

This research received no specific grant from any funding agency in the public, commercial or not-for-profit sectors. There are no conflicts of interest. M.A.A.-G. (principal investigator) did the main work of the study, including measurements of the samples, data analysis, interviewing the participants and filling in questionnaires. S.A.L.-N. contributed to data analysis and writing of the paper. J.A.K. collected samples and contributed to writing the paper. The authors are grateful to Dr David Lovell, biostatistician at the University of Surrey, and Professor Fouad Dehlawi, statistical expert at King Abdulaziz University, Jeddah, for statistical advice with respect to analysis of the data set. They thank the Joint Supervision Programme at King Abdulaziz University, Jeddah and the Centre of Excellence for Osteoporosis Research at King Fahed Medical Research Centre, Jeddah. Finally, the authors would like to formally acknowledge the referees and the journal review process, which strengthened the manuscript considerably.

\section{References}

1. El-Hajj Fuleihan G (2009) Vitamin D deficiency in the Middle East and its health consequences for children and adults. Clin Rev Bone Miner Metab 7, 77-93.

2. El-Hajj Fuleihan G, Nabulsi M, Choucair M et al. (2001) Hypovitaminosis D in healthy schoolchildren. Pediatrics 107, 53-59.

3. Dawodu A, Absood G, Patel M et al. (1998) Differential effects of 1,25-dihydroxy-vitamin $\mathrm{D}_{3}$ and 19-nor-1,25dihydroxy-vitamin $\mathrm{D}_{2}$ on calcium and phosphorus resorption in bone. J Biosoc Sci 30, 431-437. 
4. Al-Mustafa ZH, Al-Madan M, Al-Majid HJ et al. (2007) Vitamin D deficiency and rickets in the Eastern Province of Saudi Arabia. Ann Trop Paediatr 27, 63-67.

5. Musaiger AO (1996) Nutritional status of infants and young children in the Arabian Gulf countries. J Trop Pediatr $\mathbf{4 2}$, 121-124.

6. Bronner F (1976) Vitamin D deficiency and rickets. Am J Clin Nutr 29, 1307-1314.

7. Molla AM, Badawi MH, Al-Yaish S et al. (2000) Risk factors for nutritional rickets among children in Kuwait. Pediatr Int 42, 280-284.

8. Dawodu A, Varady E, Verghese M et al. (2000) Neonatal audit in the United Arab Emirates: a country with a rapidly developing economy. East Mediterr Health J 6, 55-64.

9. Abanamy A, Salman H, Cheriyan M et al. (1991) Vitamin D deficiency rickets in Riyadh. Ann Saudi Med 11, 35-39.

10. Elidrissy AT (1987) Vitamin D deficiency rickets in sunny country: pathogenesis, clinical picture and management. Ann Saudi Med 7, 99-125.

11. Elidrissy AT, A TS (1980) Rickets in Riyadh. Presented at 5th Saudi Medical Meeting, Riyadh, Saudi Arabia, 29 April1 May 1980.

12. El-Ghannam A, Ducheyne P \& Shapiro IM (1999) Effect of serum proteins on osteoblast adhesion to surface-modified bioactive glass and hydroxyapatite. J Orthopaed Res 17, 340-354.

13. Baroncelli GI, Bereket A, El Kholy M et al. (2008) Rickets in the Middle East: role of environment and genetic predisposition. J Clin Endocrinol Metab 93, 1743-1750.

14. Lubani MM, Al-Shab TS, Al-Saleh QA et al. (1989) VitaminD-deficiency rickets in Kuwait: the prevalence of a preventable disease. Ann Trop Paediatr 9, 134-139.

15. Fida NM (2003) Assessment of nutritional rickets in Western Saudi Arabia. Saudi Med J 24, 337-340.

16. Sedrani SH, Elidrissy AW \& El Arabi KM (1983) Sunlight and vitamin D status in normal Saudi subjects. Am J Clin Nutr 38, 129-132.
17. Henry CJK, Lightowler HJ \& Al-Hourani HM (2004) Physical activity and levels of inactivity in adolescent females ages 11-16 years in the United Arab Emirates. Am J Hum Biol 16, 346-353.

18. El-Sonbaty MR \& Abdul-Ghaffar NU (1996) Vitamin D deficiency in veiled Kuwaiti women. Eur J Clin Nutr 50, 315-318

19. Molla AM, Al Badawi M, Hammoud MS et al. (2005) Vitamin D status of mothers and their neonates in Kuwait. Pediatr Int 47, 649-652.

20. Dawson KP, Ameen AS, Nsanze H et al. (1996) The prevalence of group A streptococcal throat carriage in Al Ain, United Arab Emirates. Ann Trop Paediatr 16, 123-128.

21. Dawodu A, Agarwal M, Sankarankutty M et al. (2005) Higher prevalence of vitamin D deficiency in mothers of rachitic than nonrachitic children. J Pediatr 147, 109-111.

22. Siddiqui A \& Kamfar H (2007) Prevalence of vitamin D deficiency rickets in adolescent school girls in Western region, Saudi Arabia. Saudi Med J 28, 441-444.

23. Al-Jurayyan NA, El-Desouki ME, Al-Herbish AS et al. (2002) Nutritional rickets and osteomalacia in school children and adolescents. Saudi Med J 23, 182-185.

24. El-Desouki M, Othman SM \& Fouda MA (2004) Bone mineral density and bone scintigraphy in adult Saudi female patients with osteomalacia. Saudi Med J 25, 355-358.

25. Sedrani SH (1986) Are Saudis at risk of developing vitamin D deficiency? Saudi Med J 7, 427-433.

26. Glerup H, Mikkelsen K, Poulsen L et al. (2000) Commonly recommended daily intake of vitamin $\mathrm{D}$ is not sufficient if sunlight exposure is limited. J Intern Med 247, 260-268.

27. Glerup H, Mikkelsen K, Poulsen L et al. (2000) Hypovitaminosis D myopathy without biochemical signs of osteomalacic bone involvement. Calcif Tissue Int 66, 419-424.

28. Bischoff HA, Stähelin HB, Dick W et al. (2003) Effects of vitamin $\mathrm{D}$ and calcium supplementation on falls: a randomized controlled trial. J Bone Miner Res 18, 343-355. 